\title{
Erratum to: Acoustic characteristics of the sustained vowel phonation according to age groups
}

Yoon-Jeong Seo $\cdot$ Jiyoung Shin*

Department of Korean Language and Literature, Korea University, Seoul, Korea

\section{Erratum to: 모음 연장 발성이 보이는 연령대별 음향음성학적 특성 연구}

\author{
서 윤 정 - 신 지 영 \\ 고려대학교 국어국문학과
}

\section{Erratum}

말소리와 음성과학 10 권 4호에 출판된 “모음 연장 발성이 보 이는 연령대별 음향음성학적 특성 연구. 말소리와 음성과학, 10(4), 67-76. https://doi.org/10.13064/KSSS.2018.10.4.067"의 사사 문구를 저자의 요청으로 아래와 같이 수정합니다.

- 수정 전: 이 논문은 교신저자의 2017년 대한민국 교육부와 한국연구재단의 지원(NRF-2017S1A5A2A01024742)과 제1저자 의 BK21 플러스 고려대학교 한국어문학 미래인재육성사업단 의 지원으로 작성되었음.

- 수정 후 내용: 이 논문은 2017년 대한민국 교육부와 한국연 구재단의 지원을 받아 수행된 연구임 (NRF-2017S1A5A2A01024 $742)$.

\section{References}

Seo, Y. J., \& Shin, J. (2018). Acoustic characteristics of the sustained vowel phonation according to age groups. Phonetics and Speech Sciences, 10(4), 67-76.

\section{참고문헌}

서윤정, 신지영 (2018). 모음 연장 발성이 보이는 연령대별 음향 음성학적 특성 연구. 말소리와 음성과학, 10(4), 67-76.

\footnotetext{
* shinjy@korea.ac.kr, Corresponding author

(c) Copyright 2019 Korean Society of Speech Sciences. This is an Open-Access article distributed under the terms of the Creative Commons Attribution NonCommercial License (http://creativecommons.org/licenses/by-nc/4.0) which permits unrestricted non-commercial use, distribution, and reproduction in any medium, provided the original work is properly cited.
} 